\title{
Identifikasi Arsitektur Melayu: Rumah Tinggal Tradisional dan Masjid di Semenanjung Malaysia
}

\section{Identification of Malay Architecture: Traditional Houses and Mosques in Malaysia Peninsula}

\author{
Zairin Zain \\ Department of Architecture, Universitas Tanjungpura, Pontianak, Indonesia
} zairin.zain@untan.ac.id

Uray Najwa Amalia*

Departent. of Architecture, Universitas Tanjungpura, Pontianak, Indonesia uraynajwaamalia@student.untan.ac.id

Silvia Christabella

Department. of Architecture, Universitas Tanjungpura, Pontianak, Indonesia bongkaman889@student.untan.ac.id

*Correspondence author

Abstract: This study aims to describe the influence of the Malay culture and customs on the Malaysian peninsula on the architectural forms of houses and mosques. The discussion is carried out on architectural elements with the object of discussion of houses and mosques. The traditional Malay house has a house topology on stilts with high poles, a layered roof, the primary material with wooden structures, and many openings (ventilations) that illustrate adaptation to the tropical climate. The type of house is determined by its roof shape, namely Bumbung Panjang, Bumbung Limas, Bumbung Perak, and Bumbung Perak Bumbung Limas. On the other hand, a mosque is a very important building for the Malay community because it is a space for congregational prayer and a formal education/teaching center for religious education, and an administrative center for communities. The overall impression of the mosque is described as a building with a flat hypostyle roof. This typology follows a religious concept of Malaysian people regarding many aspects of design on the holiness of mosques designed to develop seven architectural elements

Keywords: Malay, Mosque, Malaysia, Typology, traditional houses

\begin{abstract}
Abstrak Kajian ini menggambarkan pengaruh budaya dan adat istiadat suku bangsa Melayu di semenanjung Malaysia terhadap wujud arsitektur rumah tinggal dan masjid. Pembahasan beberapa elemen rumah tradisional Melayu dan masjid dalam memahami pengaruh budaya dan adat istiadat suku bangsa Melayu di arsitektur bangunan. Artikel ini disusun dengan melakukan komparasi substansi dari temuan yang telah dipublikasikan dalam literatur-literatur terkait dengan arsitektur bangunan dan bangsa Melayu di Malaysia. Pembahasan dilakukan terhadap elemen arsitektur dengan objek pembahasan rumah tinggal dan Masjid. Rumah Tradisional Melayu memiliki tipologi rumah panggung dengan tiang-tiang tinggi, karakteristik atap berlapis, material utama kayu, dan banyak bukaan (ventilasi) yang menggambarkan adaptasi terhadap iklim tropis. Rumah Tradisional Melayu di Malaysia dapat dibedakan dari bentuk atap (jenis bubungan) yakni Bumbung Panjang, Bumbung Limas, Bumbung Perak, dan Bumbung Perak Bumbung Limas. Di sisi lain, masjid merupakan bangunan yang sangat penting bagi masyarakat Melayu karena aktivitas tidak hanya sebagai ruang untuk solat berjamaah namun juga sebagai pusat pendidikan/pengajaran formal pendidikan agama dan pusat administrasi. Kesan keseluruhan masjid digambarkan sebagai bangunan dengan atap hypostyle yang datar. Tipologi ini dianut secara religius oleh banyak orang di Malaysia untuk kesucian bentuk pada masjid yang diklasifikasikan dalam tujuh elemen arsitektur.

Kata Kunci: : melayu, masjid, Malaysia, tipologi, rumah tradisional
\end{abstract}

Identifikasi Arsitektur Melayu: Rumah Tinggal Tradisional dan Masjid di Semenanjung Malaysia 
Received: 2020-11-02 | Accepted: 2021-05-16 | DOI: 10.29080/eija.v7i1.1072 | Page: 42-57

EMARA: Indonesian Journal of Architecture

http://jurnalsaintek.uinsby.ac.id/index.php/EIJA

This article is open access distributed under the terms of the Creative Commons Attribution ShareAlike 4.0 International License, which permits unrestricted use, distribution, and reproduction in any medium provided the original work is properly cited.

\section{Pendahuluan}

Kita tidak dapat mengidentifikasikan identitas Melayu tidak dapat diidentifikasi dari garis keturunan atau genetiK saja, karena orang menyebut diri mereka Melayu saat ini sebenarnya adalah etnik campuran, yang mungkin bukan merupakan keturunan Melayu. studi di bidang genetika juga menyatakan bahwa etnisitas tidak memiliki basis biologis sama sekali (Brace, 2003). Menyadari bahwa Melayu adalah suatu bentuk konstruksi sosiologis, pemerintah Malaysia mendefinisikan Melayu sebagai "individu yang melaksanakan adat istiadat Melayu, berbahasa Melayu, dan memeluk Islam" (Embong et al., 2016). Tetapi definisi yang lebih mendasar dari konstruksi sosial suku Melayu adalah bahasa. Oleh karena itu, diyakini bahwa orang Melayu didefinisikan sebagai kelompok pengguna bahasa Melayu bagian dari rumpun Bahasa MalayoPolinesia Barat dari keluarga bahasa Austronesia (Aziz, 2013). Hal ini juga dipertegas oleh Angkasa (2016) bahwa Bahasa Melayu dibagi menjadi tiga sub kelompok: 44 Melayu Inti, 11 Melayu Vehikular 3, dan tiga Melayu Dayak Barat. Menurut Gaspersz, (2017) perluasan identitas Melayu melalui Islam juga mencakup penggunaan bahasa. Bahasa Melayu dipercaya berkembang melalui penyebaran Islam yang memasukkan katakata serapan dalam konsep-konsep teologis Islami dari Arab.

Total terdapat 58 varian Bahasa Melayu dengan 47 suku tersebar dari Malaysia, Brunei, Sumatera hingga ke
Papua, dan bahkan Kepulauan Cocos (Embong et al., 2016). Melayu merupakan suku Austronesia yang sudah ada sebelum masuknya agama Islam dan masyarakat Melayu awal ini menganut animisme. Masuknya agama dalam kepercayaan masyarakat Melayu memiliki pengaruh yang sangat besar terutama Islam. Saat ini hampir 100\% individu yang mengaku Melayu beragama Islam. Bangunan rumah tinggal dan Masjid merupakan peninggalan arsitektur Melayu yang masih bisa ditelusuri keberadaannya di seluruh wilayah bangsa Melayu. Menurut Prayogi, (2016) Melayu di Malaysia yang identitas kemelayuannya dari tiga kriteria, yaitu: agama Islam, mengamalkan adat budaya Melayu, dan berbicara bahasa Melayu.

Seni Bina Melayu, merupakan sebutan masyarakat Melayu mengenai rumah tradisional Melayu. Rumah tidak hanya tempat tinggal namun juga menjadi simbol kesempurnaan hidup (Effendy, 2013). Rumah Tradisional Melayu (RTM) memiliki ciri khas berupa rumah panggung dengan material utama kayu dengan kearifan lokal yang beradaptasi dengan lingkungan atau iklim, desain ruang yang minim partisi, lantai panggung, memiliki banyak jendela atau ventilasi, material bangunan yang tidak menyerap panas, dan orientasi bangunan mengarah ke barat-timur guna mereduksi sinar matahari langsung (Lim, 1987), Susunan ruang di dalam rumah Melayu memiliki penamaan yang berbeda bergantung dari lokasi daerah dan kebudayaan setempat. Namun secara garis besar memiliki fungsi 
yang sama yaitu rumah utama, rumah area servis dan anjungan. Rumah Melayu dibedakan dari bentuk atap, posisi rumah terhadap jalan raya, dan bentuk bubungan. Rumah Melayu Malaysia terdiri dari bumbung panjang, bumbung lima, bumbung perak dan bumbum perak limas. Fitur utama Rumah Tradisional Melayu di Malaysia adalah struktur atap yang terdiri dari dua bagian tiang kayu dan struktur balok, menopang atap pelana bernada tinggi yang disebut bumbung panjang (Said \& Embi, 2008). Ruang di dalam rumah tradisional Melayu disusun dengan saling relativitas satu dengan lainnya dan kedekatan ruang di dalam rumah Melayu didasarkan pada persepsi yang jelas tentang penggunaan ruang yang akan dilakukan untuk kegiatan tertentu. Penataan ruang di dalam rumah Melayu didasarkan pada prioritas ruang fungsional dan kedekatan ruang (GhaffarianHoseini \& Dahlan, 2012).

Masjid merupakan bangunan penting bagi orang melayu karena menjadi tempat melakukan kegiatan ibadah seperti sholat berjamaah dan pendidikan formal agama (Rumondor \& Manese, 2020). Masjid Tradisional Melayu Malaysia memiliki ciri pada perletakan lantainya memiliki elevasi dari permukaan tanah dan bentuk atapnya (Utaberta \& Rasdi, 2010). Masjid tradisional memiliki banyak persamaan dengan rumah tradisional salah satunya pada elevasi lantai dan bentuk panggung. Masjid Malaysia memiliki beranda ruang yang mirip serambi tertutup yang mengelilingi ruang sholat utama. Ruang ini berfungsi untuk menampung jamaah, tempat makan dan bersantai agar tidak mengotori kesucian ruang sholat. Pada bagian struktur masjid tradisional menempatkan tiang utama pada bagian tengah bangunan (Johar et al., 2013). Seiring perkembangan jaman dan peristiwa sejarah terjadi perubahan dan pengembangan arsitektur melayu yang dipengaruhi oleh teknologi, budaya dan akulturasi budaya asing, sehingga saat ini tercatat terdapat tujuh gaya bahasa arsitektur yang diterapkan di Masjid Malaysia.

Dalam memahami budaya dan adat istiadat Melayu di Malaysia dapat dilakukan dengan mengidentifikasi karya arsitektur dari kedua jenis bangunan ini. Pengaruh budaya dan adat istiadat Melayu diyakini diterapkan sebagai elemen arsitektur yang ditemukan pada rumah tradisional dan masjid suku Melayu di Semenanjung Malaysia. Adat dan istiadat berhubungan yang erat dengan kehidupan masyakarat Melayu sebagai alat yang berupaya mengatur kehidupan (Tamrin, 2017). Arsitektur Melayu dipengaruhi oleh adat, istiadat dan budaya Melayu dimana bangunan tersebut didirikan. Arsitektur bangunan dari rumah dan masjid tradisional di setiap permukiman memalyu memiliki ciri-ciri khas yang melekatkan budaya dan adat isitiadat. Oleh karena itu, rumah tinggal dan masjid tradisional di Semenanjung Malaysia perlu diidentifikasi lebih jauh. Menurut Effendy (2013), budaya dalam membangun rumah kadang diperlukan musyawarah antar keluarga bahkan masyarakat setempat. Dipahami di masyakarat jika seseorang yang mendirikan rumah tanpa mengadakan musyawarah akan dianggap sebagai "kurang adab" atau "tak tahu adat".

\section{Metode}

Artikel ini melakukan komparasi substansi terkait dengan arsitektur bangunan suku bangsa Melayu di Malaysia yang didapat dari artikel ilmiah yang telah dipublikasikan sebelumnya. Artikel ilmiah ini disusun mengunakan metode text-incontext dan paradigm kualitatif. Menurut Sandelowski et al., (2013) . Metode text-incontext ini melakukan ekstraksi temuan dari artikel penelitian yang telah 
dilakukan dan termasuk didalamnya artikel yang menggunakan metode penelitian campuran dan studi penelitian sintesis. Dalam studi ini akan melakukan pendalaman dari substansi temuan yang disampaikan dalam penelitian terdahulu dengan teknik komparasi. Pembahasan yang dilakukan difokuskan pada elemen arsitektur yang terlihat pada fasad seperti bentuk atap dan bukaan rumah tinggal dan Masjid tradisional di Semanjung Malaysia dengan mengambil beberapa studi kasus yang ditelah dibahas pada artikel terpilih.

\section{Hasil dan Pembahasan \\ Rumah Tinggal Melayu}

Rumah Melayu merupakan salah satu warisan budaya terbesar Malaysia. Dirancang dan dibangun sendiri oleh penduduk desa dengan ketrampilan dan kekreatifan serta estetika orang Melayu. Umumnya arsitektur Melayu merupakan rumah panggung dan memanjang, sebagai bentuk adaptasi tinggal di kawasan tropis kepulauan dengan tanah berawa-rawa dan hutan lebat. Rumah panggung berguna untuk mengatasi risiko banjir dan hewan buas di pesisir dan rimba, sementara bentuk memanjang digunakan untuk mempermudah perluasan rumah dalam memenuhi kebutuhan sosial dan keamanan Bidang bangun arsitektur Melayu dapat dilihat pada gambar 1 . Tidak hanya mencangkup bentuk rumah arsitektur rumah Melayu memiliki atap berlapis (bisa sampai tiga lapis) dengan teritisan lebar, tiang (kolom) bulat dan tanpa loteng (Hassan \& Nawawi, 2014). Selain itu, rumah Melayu juga memiliki banyak bukaan yang memaksimalkan pemanfaatan cahaya alami dan angin (Hosseini et al., 2016) (lihat gambar2)
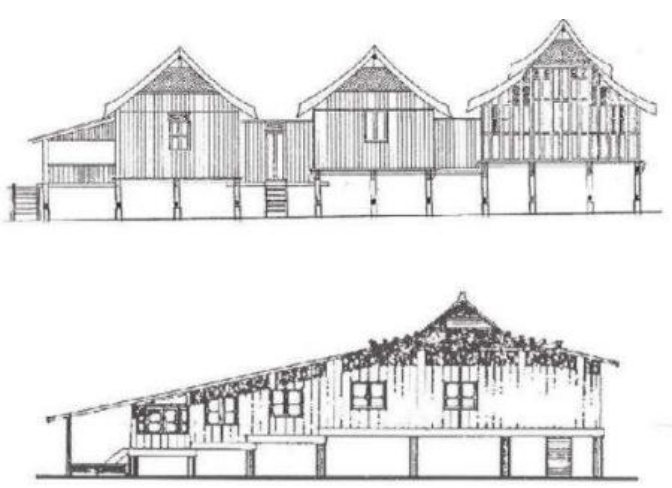

Gambar 1: Bentuk Umum Rumah Melayu (Sumber:Said \& Embi, 2008)

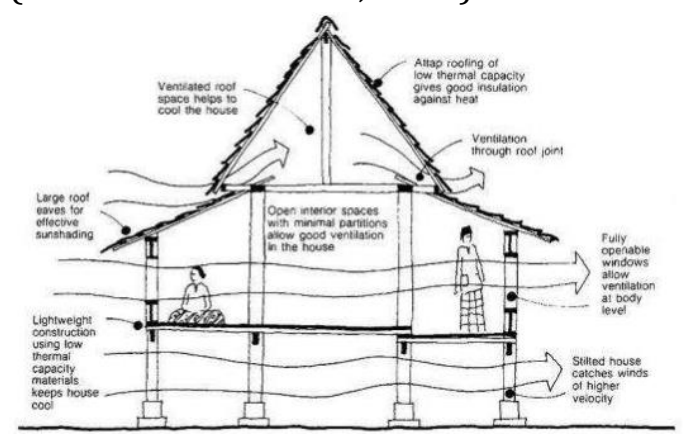

Gambar 2: Rumah Melayu dengan Aliran Ventilasi Udara Alami (Sumber (Lim, 1987)

Pada dasarnya rumah tradisional Melayu dapat dibagi menjadi dua yakni bagian depan dan bagian belakang yang berpusat di sekitar rumah ibu (inti rumah) dan dapur (gambar 3).

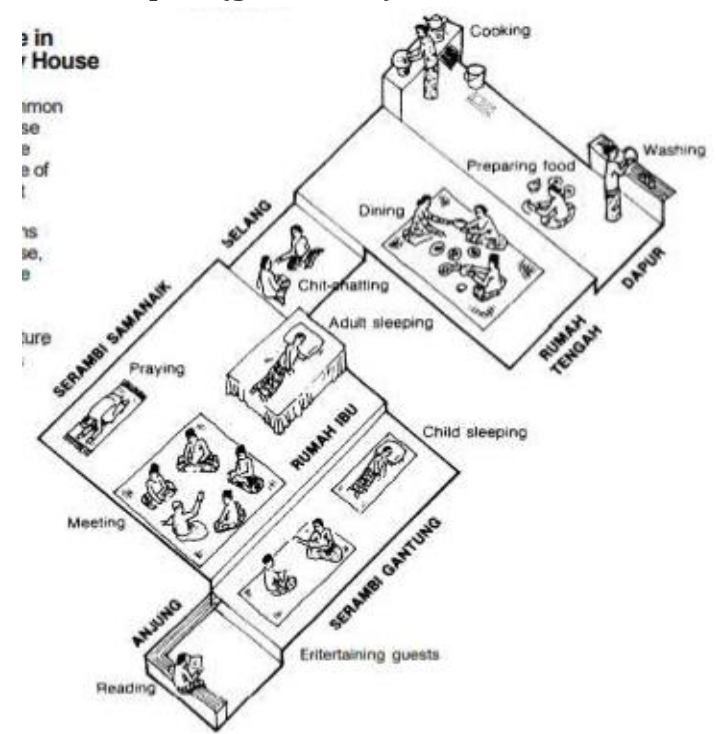

Gambar 3: Desain dan layout rumah tradisional Melayu (Sumber: Lim, 1987) Area bawah pada rumah dijadikan tempat untuk menyimpan kendaraan, kayu bakar 
bahkan hasil panen seperti padi (lingkungan rumah Melayu dapat dilihat pada gambar 4). Berbagai bentuk rumah Melayu tradisional dan hibrida dapat diidentifikasi di Semenanjung Malaysia. Rumah Melayu diklasifikasikan terutama berdasarkan bentuk atapnya. Dasar Bentuk rumah tersebut adalah Bumbung Panjang, Bumbung Lima, dan Bumbung Perak Bumbung Limas (Lim, 1987)

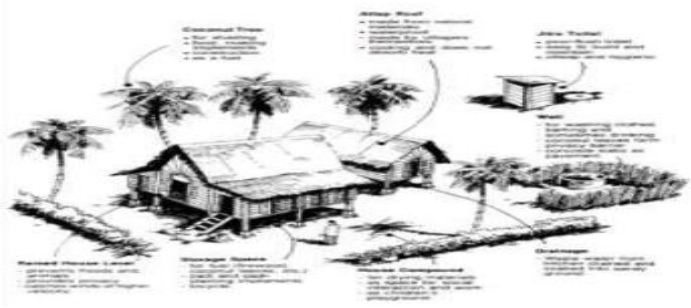

Gambar 4: Lingkungan eksternal rumah Melayu (Sumber: Lim, 1987)

\section{Rumah Bumbung Panjang}

Rumah tradisional Bumbung Panjang tersebar di berbagai daerah di Malaysia karena bumbung panjang merupakan bentuk rumah paling sederhana dan efisien dalam pola ventilasi dan memperus ruang. Rumah bumbung panjang memiliki atap pelana yang didukung oleh tiangtiang raja, dan tebar layar (Said \& Embi, 2008). Rumah tertua yang diidentifikasikan di Malaysia merupakan Rumah bumbung Panjang Penang yang diperkirakan berusia lebih dari satu abad. Rumah bumbung panjang juga berada di daerah Kedah, Melaka, Kelantan, Minangkabau, Perlis, Perak, Negeri Sembilan, Selangor dan Kepulauan Pinang dengan ciri khas masing-masing daerah (lihat tabel 1).

Tabel 1. Perbandingan bentuk bumbung dan ciri khas Rumah Tradisional Melayu di Malaysia

\begin{tabular}{|c|c|c|c|c|}
\hline $\begin{array}{l}\mathbf{N} \\
\mathbf{0}\end{array}$ & $\begin{array}{l}\text { Bentuk } \\
\text { atap }\end{array}$ & Daerah & Ciri khas & $\begin{array}{l}\text { faktor perubahan } \\
\text { arsitektur }\end{array}$ \\
\hline \multirow[t]{6}{*}{1} & $\begin{array}{l}\text { Bumbung } \\
\text { Panjang }\end{array}$ & Melaka & $\begin{array}{l}\text { bumbung curam berloteng } \\
\text { (Said \& Embi, 2008) }\end{array}$ & $\begin{array}{l}\text { - iklim } \\
\text { - sumber daya alam }\end{array}$ \\
\hline & & $\begin{array}{l}\text { Negeri } \\
\text { Sembilan }\end{array}$ & $\begin{array}{l}\text { Bentuk atap memanjang dan bubungan sedikit } \\
\text { melengkung dikedua ujung atap (sumber: Wahab } \\
\text { \& Bahauddin, 2019) }\end{array}$ & $\begin{array}{l}\text { - teknik konstruksi } \\
\text { - budaya local }\end{array}$ \\
\hline & & Penang & $\begin{array}{l}\text { disebut rumah gajah menyusu karena rumah ibu } \\
\text { yang lebih tinggi dari rumah anak dan serambi } \\
\text { dianggap seperti anak gajah menyusu. } \\
\text { (sumberHassan \& Nawawi, 2014) }\end{array}$ & \\
\hline & & Kedah & $\begin{array}{l}\text { Memiliki tabir layar dari pelepuh tiga segi } \\
\text { (sumber:(Harun, 2005) }\end{array}$ & \\
\hline & & Kelantan & $\begin{array}{l}\text { memiliki ukiran rumit pada rumah } \\
\text { menggambarkan status penghuni rumah dan } \\
\text { atap berbentuk huruf "alif lam" terbalik. } \\
\text { (sumber: Choo et al., 2020) }\end{array}$ & \\
\hline & & Perlis & $\begin{array}{l}\text { Memiliki banyak tiang ( } 24 \text { tiang pada rumah ibu) } \\
\text { (sumber: Choo et al., 2020) }\end{array}$ & \\
\hline 2 & $\begin{array}{l}\text { Bumbung } \\
\text { Limas }\end{array}$ & $\begin{array}{l}\text { Johor, } \\
\text { terengganu }\end{array}$ & $\begin{array}{l}\text { terdapat ukiran di tepi atap, pada ujung } \\
\text { bubungan dipasang kayu tajam yang disebut } \\
\text { tunjak langit, bentuk atap dipeengaruhi } \\
\text { arsitektur belanda dan inggris (sumber:(Hassan } \\
\text { \& Nawawi, 2014) }\end{array}$ & $\begin{array}{l}\text { - } \text { estetika } \\
\text { - budaya luar } \\
\text { - kepercayaan }\end{array}$ \\
\hline 3 & $\begin{array}{l}\text { Bumbung } \\
\text { Perak }\end{array}$ & Perak & $\begin{array}{l}\text { Disebut juga rumah kutai, memiliki } 12 \text { dan } 16 \\
\text { tiang di rumah induknya dan berhias ukiran } \\
\text { lebah bergantung. (sumber: (Afifi, 2017) }\end{array}$ & $\begin{array}{l}\text { - akulturasi budaya } \\
\text { - globalisasi }\end{array}$ \\
\hline
\end{tabular}

Sumber: Kompilasi dari berbagai sumber, 2020

End one

\section{Rumah Bumbung Lima}

Rumah Bumbung Lima merupakan rumah tradisional dengan ciri atap karakter 3 dimensi yang terdiri dari 1 bubungan utama ditengah atap diikuti bubungan yang lebih kecil turun hingga ke lekukan 
atap (Nasir, 1985). Contoh rumah lima di Malaysia terdapat pada rumah dari Johor (lihat tabel 2) dengan pengaruh arsitektur bugis, banjar, jawa dan belanda (Nasir, 1985).

\section{Rumah Bumbung Perak Bumbung Limas}

Rumah Bumbung Perak Bumbung Limas merupakan evolusi dari Bumbung Lima, yang terdiri dari beberapa ruang serambi, anjung. Selain itu komposisi bangunan tediri dari rumah ibu dan dapur yang dibatasi oleh selang. Rumah ini memiliki fleksibelitas dalam perluasannya karena dapat diperluas sesuai kebutuhan memanjang ke belakang rumah. Atap anjung terdiri dari bumbung limas perak, sedangkan serambi menggunakan bumbung pisang sesikat. Elemen dekoratif pada rumah dihias dengan motif gerbang janda. Contoh rumah bumbung limas yang terdapat di Malaysia adalah rumah limas Terengganu (lihat pada tabel 1) yang dikenal dengan rumah duduk, style belanda, rumah bujang barat dan rumah duduk bujang bersorong (Nasir, 1985)

Tabel 2. Jenis-jenis Rumah Melayu dan Daerah di Malaysia

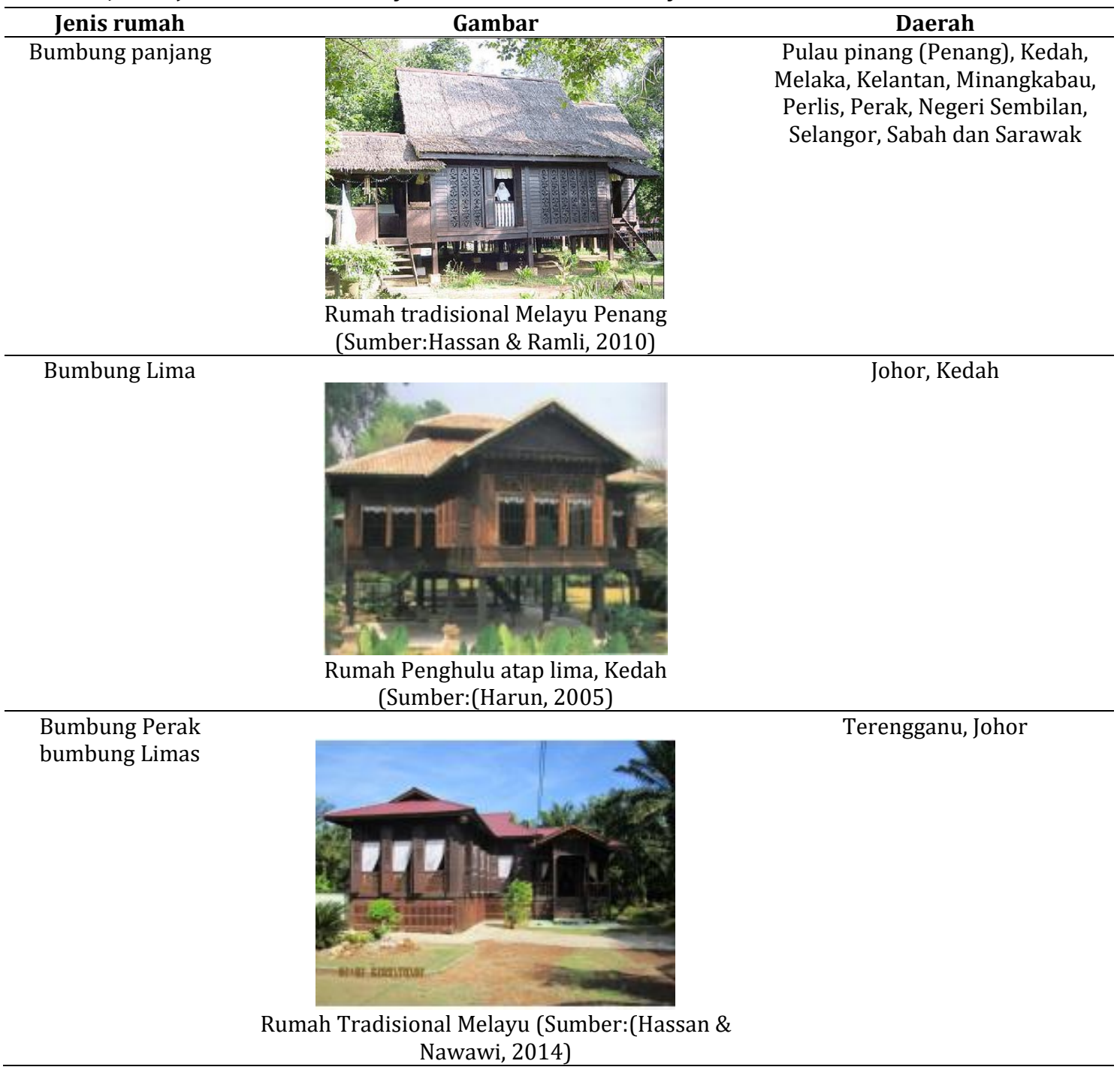

Arsitektur bentuk atap bangunan di Malaysia ini mirip dengan penamaan bentuk yang ditemukan di pulau Sumatera
(Firzal, 2011). Jenis atap ini menjadi ciri arsitektur bentuk bangunan Melayu yang mudah dikenal, selain identitas konstruksi 
panggung dan material kayunya. Bentuk atap pelana ini ditemukan di semua arsitektur tradisional Melayu di Kalimantan dan Sumatera memberikan volume ruang besar dibawah untuk kebutuhan aktivitas dan penyesuaian disain dengan kondisi lingkungan sekitar (Firzal, 2011; Zain, 2016).

Tabel 2 juga memperlihatkan ciri khas sebagai identitas rumah Melayu yang umum ditemukan di kawasan Sumatera, Semenanjung Malaysia dan Kalimantan. Keberadaan bukaan pintu dan jendela yang besar juga menjadi identitas elemen arsitektur yang mudah ditemukan pada rumah tradisional Melayu. Identitas ini juga disampaikan dalam pembahasan rumah tradisional di Kalimantan Barat (Zain, 2016).

Tabel 2 juga memperlihatkan jenis-jenis rumah tradisional di Malaysia yang disajikan berdasarkan bentuk aktifnya. Tipikal atap memperlihatkan komposisi bentuk dengan satu atau dua susun dengan pola memanjang atau melintang. Bentuk seperti ini lazin ditemukan pada bentuk atap di pulau Sumatera dengan konstruksi panggung dan pondasi yang umpak diatas tanah. Kemiringan atap yang tinggi dengan tekukan pada pada bidangnya juga menjadi ciri rumah tradisional Melayu di hampir seluruh wilayah nusantara. Bentuk seperti ini dimaksudkan untuk mengantisipasi kondisi lingkungan dan temperatur di kawasan ini. Bentuk atap seperti ini menciptakan ruang dibawahnya untuk membuat perangkap bagi udara panas dan mengeluarkannya melalui ventilasi di beberapa sisi atap jenis ini. Konstruksi panggung juga memberikan resapan air permukaan dan sirkulasi udara yang berperan dalam menstimulus suhu yang nyaman pada ruangan diatas lantai. Menurut (Firzal, 2011), tiang bangunan panggung di Sumatera bisa diletakan diatas batu atau diikatkan ke struktur sederhana tanpa harus ditanam ke dalam tanah

\section{Arsitektur Masjid}

Masjid tradisional Malaysia memiliki karakter atap yang tidak jauh berbeda dengan masjid yang ada di Indonesia yakni bentuk limas dan bertingkat-tingkat (Utaberta \& Rasdi, 2010). Tipologi masjid paling awal di Malaysia adalah diyakini murni terbuat dari material kayu dengan karakteristik atap piramida dua tingkatan tipe atap pelana panjang (Asif et al., 2019). Gaya masjid vernakular tradisional dan Sino-Elektrik yang mempunyai nilai seni lebih tinggi dibandingkan dengan masjid yang mempunyai karakteristik modern seperti gaya India baru, vernakular modern, modernistik dan modern revivalism (tabel 2). Hal ini dikarenakan masjid tua atau klasik masih menonjolkan unsur literatur tradisional dan budaya. Semenanjung Malaysia terdapat tujuh gaya penerapan bahasa arsitektur masjid. Setiap Gaya Bahasa arsitektur masjid memiliki perbedaan dan persamaan dalam karakteristik maupun tipologinya

\section{Gaya Vernakular Tradisional}

Desain masjid tradisional di Malaysia lebih menonjolkan karakter atapnya yakni berbentuk limas dan bertingkat-tingkat. Ciri yang khas dari susunan ruang dan lantainya. Tipologi bentuk atap masjid tradisional Malaysia mirip rumah tradisionalnya dengan ciri struktur kayu yang diangkat dari permukaan tanah. Struktur kayu ini memungkinkan masjid dapat dipindahkan dari tempat asalnya. 
Tabel 3. Perbandingan Elemen Masjid Malaysia

\begin{tabular}{|c|c|c|}
\hline $\begin{array}{c}\text { Gaya Bahasa Arsitektur } \\
\text { Masjid }\end{array}$ & Gambar dan Sumber & Penjelasan Elemen Masjid \\
\hline Gaya Vernakular masjid & & $\begin{array}{l}\text { Elemen Klasifikasinya menjelaskan ciri-ciri } \\
\text { dari arsitektur melayu tersebut, bentuk } \\
\text { elemennya mengkombinasikan arsitektur } \\
\text { masjid tradisional dan Sino-Elektrik. }\end{array}$ \\
\hline Gaya Sino-Elektrik & Sun & $\begin{array}{l}\text { Elemen masjid ini banyak mendapat } \\
\text { pengaruh dari arsitektur cina, bentuk, } \\
\text { karakter pada masjid yang khas ialah pada } \\
\text { lantai dasarnya yang melekat pada tapak, } \\
\text { butiran-butiran masjid, pembagian dasar, } \\
\text { tengah, atas dengan tiang ganda yang } \\
\text { menyongkong gerbang dan dinding yang } \\
\text { melengkung dan dilengkapi dengan plaster }\end{array}$ \\
\hline Gaya India Utara & & $\begin{array}{l}\text { Elemen masjid india utara menggambarkan } \\
\text { ide yang tidak rasional, yang } \\
\text { mengkombinasikan antara arsitektur klasik } \\
\text { digunakan untuk gereja dan bangunan awam } \\
\text { di inggris dibuat dengan struktur batu, dan } \\
\text { system tertutup bagian atap dengan kubah, } \\
\text { penggunaan elemen tersebut dikarenakan } \\
\text { perkembangan kelas pedagang india cina } \\
\text { dan muslim terhadap banyaknya pusat } \\
\text { komersial }\end{array}$ \\
\hline Gaya Vernakular Modern & $\begin{array}{l}\text { (Sumber.Nasir, 1985) } \\
\text { (Sumbering }\end{array}$ & $\begin{array}{l}\text { Elemen masjd ini menggunakan struktur } \\
\text { atap tebar layer dengan sebuah kubah kecil } \\
\text { dan kubah besar yang menutupi ruang } \\
\text { sholat utamanya, masjid membentuk sebuah } \\
\text { bujur sangkar yang dihiasi dengan elemen } \\
\text { gerbangm dan kubah kecil maupun besar }\end{array}$ \\
\hline Gaya Modernistik & 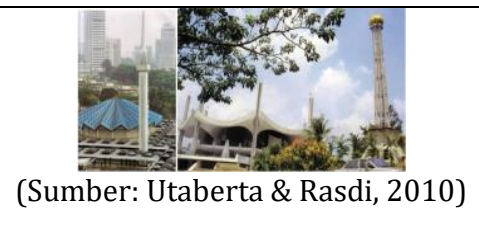 & $\begin{array}{l}\text { Elemen tersebut membentuk metafora } \\
\text { melalui ekspresi struktur dengan } \\
\text { memperlihatkan gaya-rupa yang sama, } \\
\text { penggunaan kuda-kuda keluli difungsikan } \\
\text { untuk merentangkan bumbung tegasan } \\
\text { tensile sebagai bahan penutup atapnya. }\end{array}$ \\
\hline Gaya Modern Revivalism & (Sumber: (Utaberta \& Rasdi, 2010) & $\begin{array}{l}\text { Elemen masjid ini meghubungkan antara } \\
\text { kritik masjid status quo dengan kerangka } \\
\text { identitas regional dari islam, perletakan } \\
\text { masjid berada di teengah-tengah danau } \\
\text { buatan. Elemen struktur nya terbuat dari } \\
\text { beton bertulang dengan kubah keluli dengan } \\
\text { marmer dan keramik mahal melapisi } \\
\text { seluruh dinding dan lantai masjid, }\end{array}$ \\
\hline Gaya Klasik Eropa & (Sumber: (Utaberta \& Ra & $\begin{array}{l}\text { Elemen tersebut menggunakan pembagian } \\
\text { definitif alas tengah, serta bagian atas } \\
\text { dengan kolom ganda yang menopang } \\
\text { lengkungan dengan komposisi simetris yang } \\
\text { kuat dari massa dan ruang fitur pengenal. }\end{array}$ \\
\hline
\end{tabular}

Jenis masjid yang memiliki atap berlapis tiga ditemukan pada Masjid Kampung Laut dan Masjid Kampung Tuan (gambar5).
Bentuk atap piramida dengan di topang kolom menjadikan masjid jenis ini memberikan volume ruang besar 


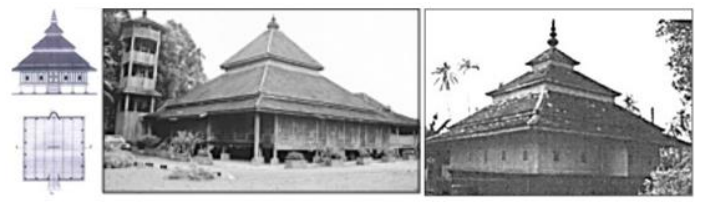

Gambar 5: Masjid Kampung Laut dan Masjid Kampung Tuan (Sumber: Nasir, 1985).

Jenis masjid yang memiliki atap berlapis dua ditemukan pada Masjid Papan (gambar 6) dan Masjid Lenggeng (gambar 7).

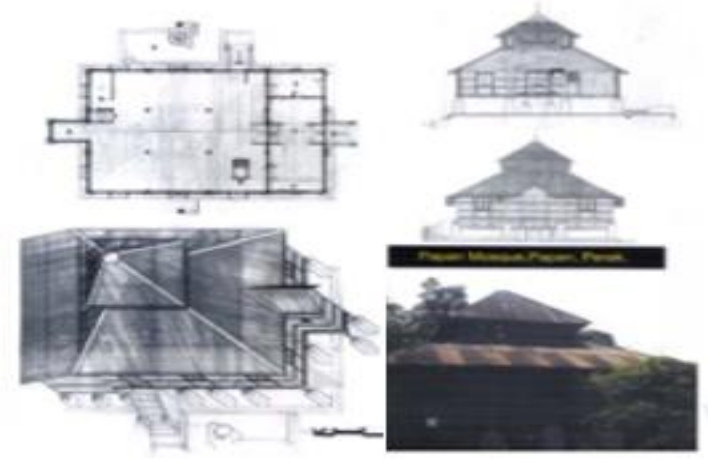

Gambar 6. Masjid Papan (Sumber:Nasir, 1995).
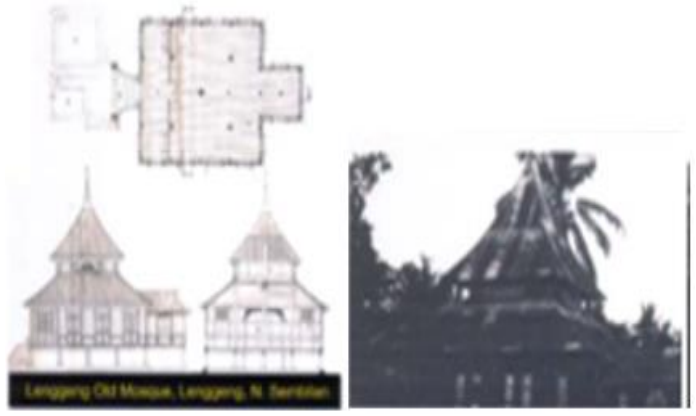

Gambar

7. Masjid

Lenggeng

(Sumber:Nasir, 1995).

Kedua Jenis atap masjid tersebut berbentuk atap piramidal dua tingkat yang menonjolkan jeda antar 2 bentuk atap. Jeda ini umumnya dimaksudkan untuk memasukan cahaya atau udara

Jenis masjid ketiga yang memiliki atap memanjang berbentuk pelana sebagaimana dapat dilihat pada Masjid Langgar (gambar 8). Pada tipologi ini berupa bentukan atap tingkat tunggal atau ganda. Ciri khas masjid ini berupa peninggian dari pinggang ke bahu bangunan.
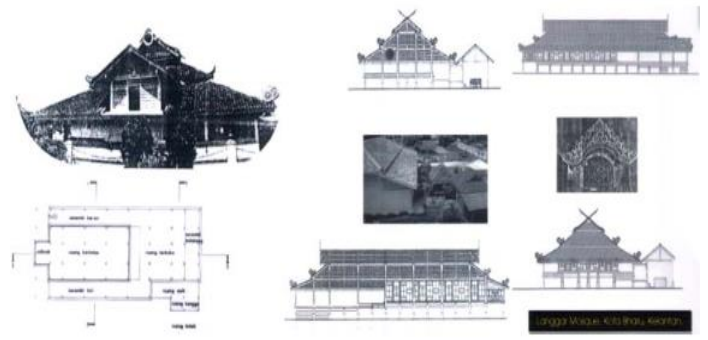

Gambar 8. Masjid Langgar (Sumber:Nasir, 1995).

Masjid-masjid ini tidak membangun Menara dengan ciri khas bangunan tunggal dan ruang terbuka. Pada kasus tertentu, struktur atap menjulang bebas tanpa kolom penopang seperti di Masjid Kampung Tuan. Formasi seperti ini tentunya berbeda dengan masjid tradisional lainnya yang menggunakan sistem struktur tiang penopang di tengah bangunan. Sistem struktur seperti ini menjadi pembeda terhadap bangunan masjid tiga tingkat yang lain.

Konstruksi masjid tradisional di Malaysia hanya berupa sebuah ruang tunggal yang terbuka dan tanpa pagar. Dan menggunakan struktur rangka ruang kayu yang unik dan secara lokal dikenal sebagai sistem konstruksi tiang gantung diatas tanah(Rasdi \& Tajuddin, 2007).

\section{Gaya Sino-Eklekti}

Masjid Sino-Eklektik juga merupakan kategori masjid tua di Malaysia dan banyak ditemukan di Melaka Melaka (lihat gambar 9, 10, 11, 12)..Masjid jenis ini mendapat pengaruh dari Arsitektur Cina pada elemen-elemen bangunan dan bentuk arsitekturnya. Gaya Sino-Eklektik menggambarkan pengaruh budaya luar yang beradaptasi dengan budaya setempat (Ahmad, 2015). Karakter dari jenis ini adalah lantai dasarnya yang dikonstruksikan diatas tanah. Masjid jenis ini dikelilingi oleh pagar dan memiliki gerbang (Azhari \& Mohamed, 2012). Masjid ini memiliki lantai yang ditinggikan sekitar setengah meter dengan tangga batu sebagai akses ke ruang utama. Denah 
masjid terdiri dari area sholat tertutup dan serambi atau beranda. Area wudhu dan kuburan menjadi bagian utama dari kompleks masjid. Struktur Bubungan atap, lisplang dihiasi motif tanaman dan puncak atap bermahkotakan mastaka. Bentuk atap masjid jenis ini bersusun ganda. Ciri umum berupa bagian tengah atap yang ditopang oleh empat pilar dan pilar-pilar lainnya di sekelilingnya (Rasdi \& Tajuddin, 2007).

Bentuk atap dalam klasifikasi ini ini terdapat dua bagian, yaitu masjid dengan atap yang berlapis dua dengan masjid dengan atap yang berlapis tiga. Masjid Sino-Eklektik yang bertingkat tiga dapat ditemukan pada Masjid Kampung Hulu, Masjid Tengkera, dan Masjid Kampung Keling di Melaka atau Masjid Undang Kamat dan beberapa masjid lain di Negeri Sembilan, sedangkan yang bertingkat dua dapat ditemukan pada Masjid Undang Serun di Negeri Sembilan. Berbeda dengan masjid tradisional yang terletak di daerah perkampungan, masjid jenis ini banyak terdapat di perkotaan seperti Melaka, Penang dan Negeri Sembilan.
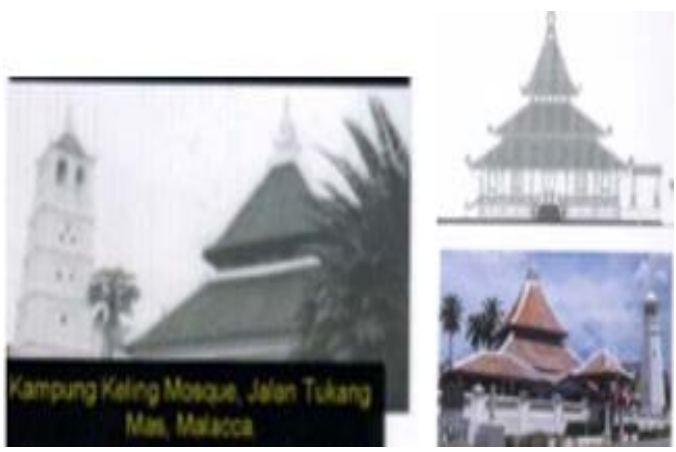

Gambar 9. Masjid kampung keling (Sumber:Nasir, 1995).

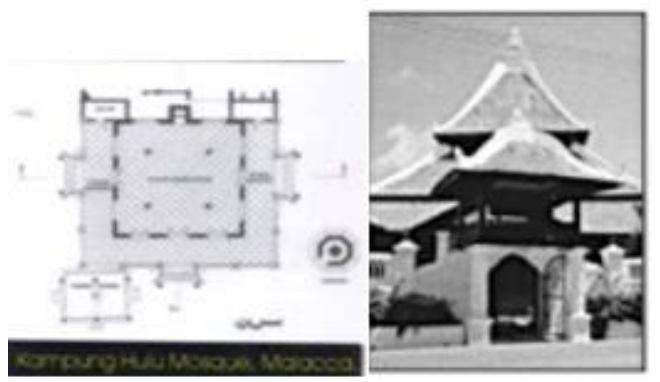

Gambar 10. Masjid kampung Hulu (Sumber:Nasir, 1995).
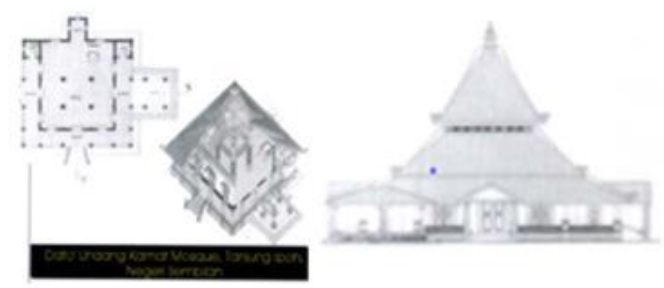

Gambar 11 Masjid Daro Undang Kamat di Negri Sembilan (Sumber:(Nasir, 1995).
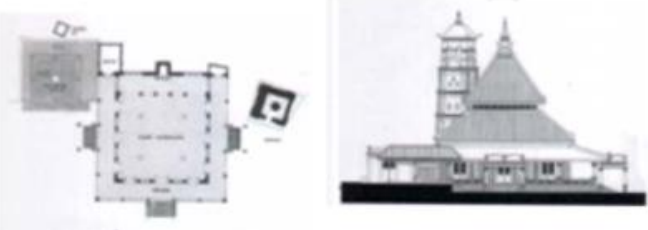

Gambar 12: Masjid Masjid Tengkera di Melaka (Sumber:(Nasir, 1995).

\section{Gaya Klasik Eropa}

Masjid Sultan Abu Bakar di Johor Bahru dilengkapi dengan empat menara dengan kubah kecil di puncaknya (lihat gambar 13). Bentuk ini menjadi Karakteristik utama dari elemen gaya klasik eropa dengan pembagian tiga elemen utama dari bangunan yaitu dasar, tengah, dan atas dengan tiang ganda. Komposisi simetri yang kuat pada penyusunan massa dan ruang bangunan menjadi salah satu elemen khasnya. Ruang salat utama memiliki atap dengan naungan tertutup. Jendela juga dibingkai oleh lapisan cornice yang diplester (Rasdi \& Tajuddin, 2007), 


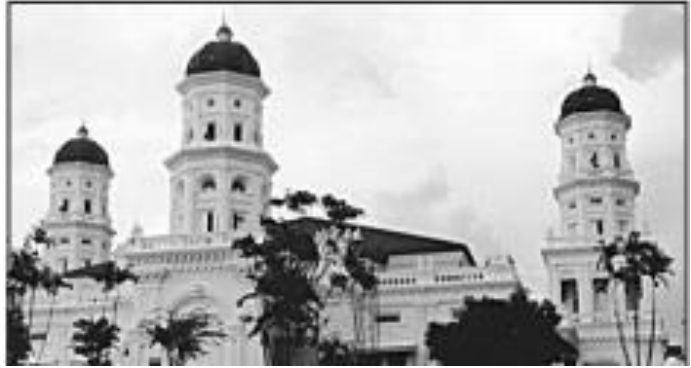

Gambar 13: Masjid Negeri Sultan Abu Bakar (Sumber: Utaberta \& Rasdi, 2010)

\section{Gaya India Utara}

Diantara masjid bergaya India Utara di Makaysia adalah Msjid Ubudiah, Masjid Jamik, Masjid India, Masjid Kapitan Keling dan masjid Alwi (lihat gambar 14-18). Tipologi Masjid India Utara di Malaysia mendeskripsikan peniruan terhadap gaya India Moghul dengan penggunaan kubah bawang berukuran besar dan kecil. Selain itu, elemen satu atau lebih menara dengan beragam ketinggian, kanopi berbentuk kubah kecil, gerbang berbentuk sarung kaki kuda dengan tiang yang penuh dekorasi, lengkungan multifoil di kolom yang dihias (Utaberta \& Rasdi, 2010)

Pola ruang pada denah masjid mempunyai karakteristik berupa kubah bagian tengah dan serambi dengan gerbang. Masjid memiliki pagar keliling beserta tempat parkir dan padang rumput di halamannya. Struktur masjid menggunakan beton dan sistem tertutup. Bentuk masjid ini menjelaskan gaya India Utara pernah menjadi pilihan aliran bentuk masjid yang berkembang dan mengasosiasikan Islam pda bentuk masjid kepada gaya tradisional India dari pedagang yang datang di Taiping dan Penang.

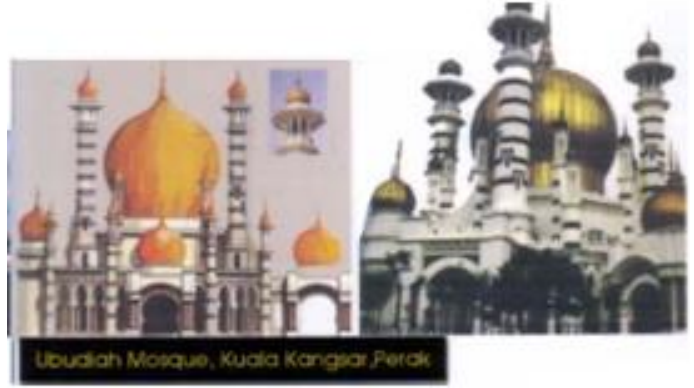

Gambar 14: Masjid Ubudiah (Sumber: (alĀṭī, 1998)

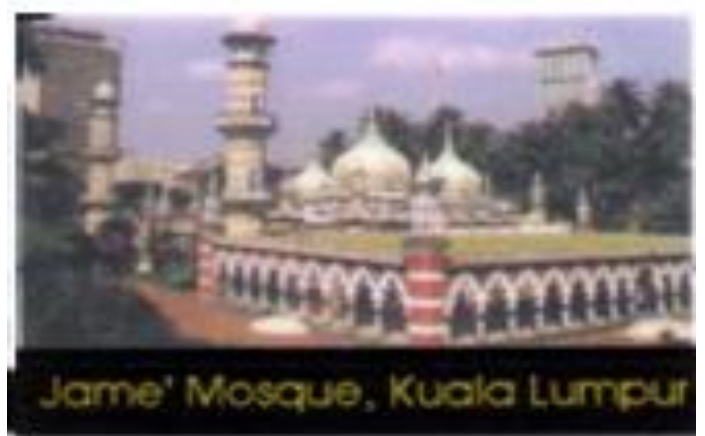

Gambar 15: Masjid Jamik (Sumber: (al-Āṭ̂̄, 1998)

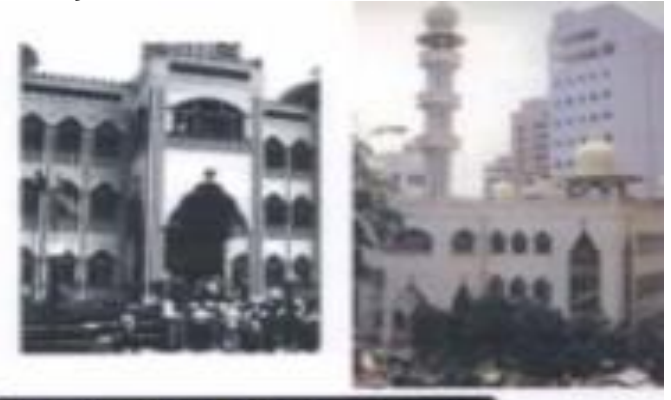

Masid inda. Kuala tunku

Gambar 16: Masjid India (Sumber: (al-Āṭī, 1998)

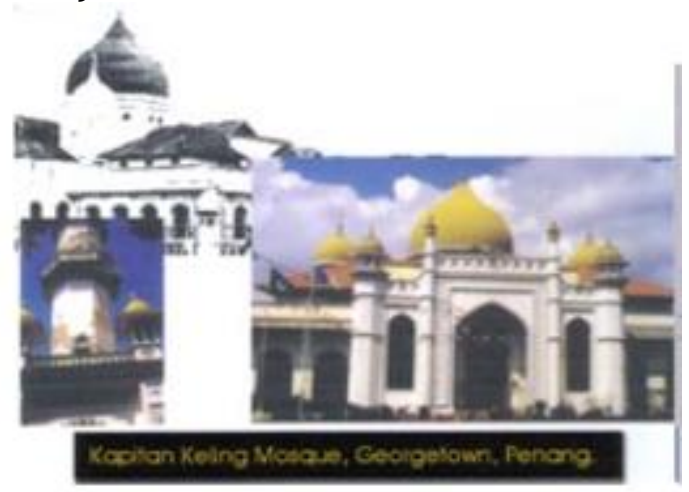

Gambar 17: Masjid Kapitan Keling (Sumber: (al-Āṭī, 1998)

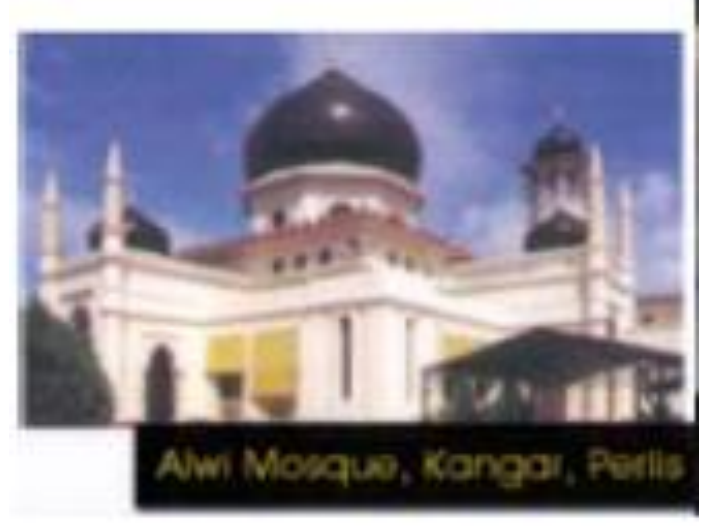

Gambar 18: Masjid Alwi (Sumber: (al-Āṭī, 1998) 


\section{Gaya Vernakular Modern}

Istilah masjid Modern Vernakular merujuk kepada bangunan yang dibangun dengan struktur beton bertulang dengan dinding batako atau batu bata. Masjid dengan gaya ini menggunakan atap bentang lebar sederhana atau piramida dengan sebuah kubah kecil. Masjid tertentu menggunakan material bentang lebar dari kayu dan sebagian yang lain terbuat dari beton. Pola denah masjid jenis ini berupa ruang sholat untuk wanita di bagian belakang ruangan dengan tirai atau partisi. Sebagian besar masjid ini memiliki satu atau dua menara. Sistem struktur utama yang digunakan adalah tiang beton bertulang dan sistem balok dengan bata diplester atau balok pengisi. Atapnya dari bahan ringan atau tanah liat. Struktur atapnya dari kayu atau rangka besi dengan lantai keramik dan jendela bahan aluminium (Utaberta \& Rasdi, 2010). Beberapa contoh masjid dengan gaya vernakular modern di Malaysia dapat dilihat pada gambar 19-22 berikut

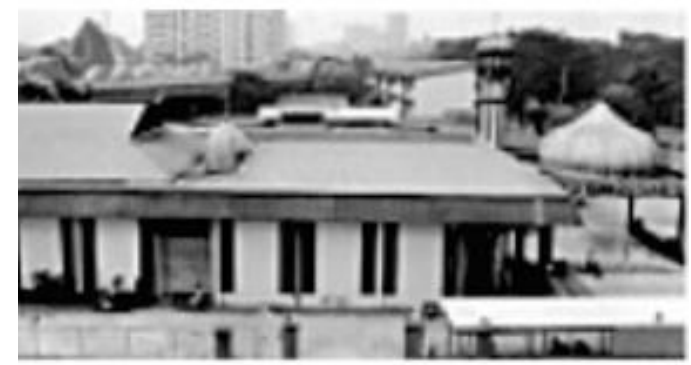

Gambar 19: Masjid Alam Shah (Sumber:Nasir, 1995).

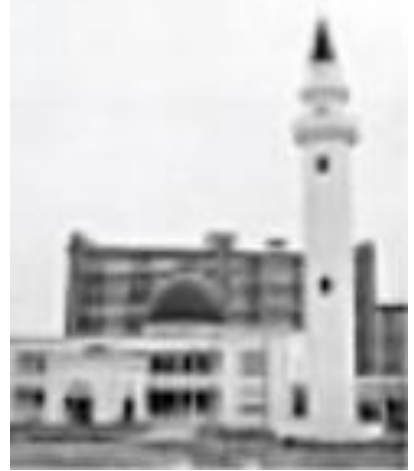

Gambar 20: Masjid Idris Al-Marbawi (Sumber:Nasir, 1995).

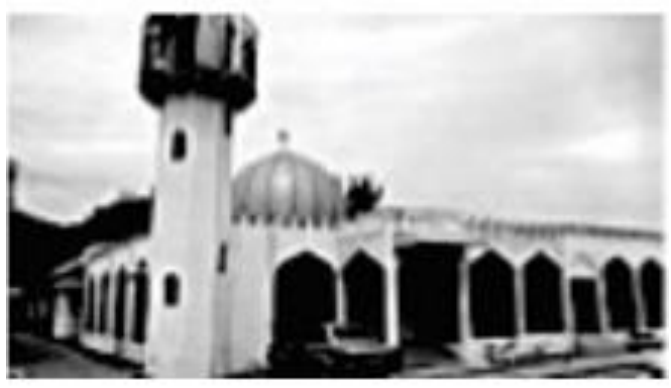

Gambar 21: Masjid Al-Ubudiah (Sumber:Nasir, 1995).

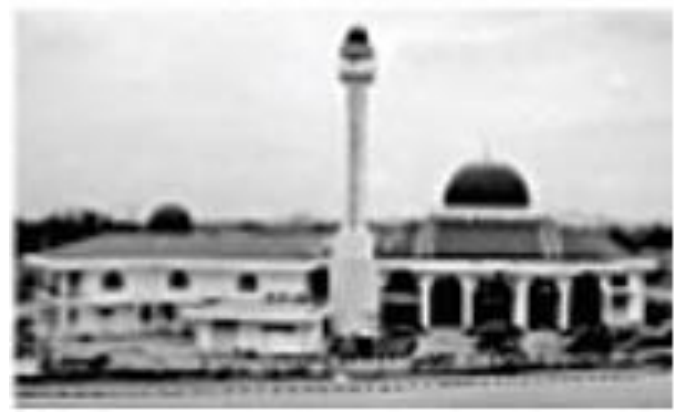

Gambar 22: Masjid Kampung Batu Muda (Sumber:Nasir, 1995).

\section{Gaya Modernistik}

Bangunan Modernistik Ekspresionisme memiliki ide dan prinsip utama yang mengarahkan revolusi arsitektur di Eropa di awal kurun ke-20. Ada dua jenis gaya modernistik di masjid Malaysia yaitu Ekspresionisme Modernistik dan Strukturalisme Modern. Ada dua masjid dalam kategori ini di Malaysia yaitu Masjid Negara dan Masjid Negeri Sembilan (gambar 23 dan 24)

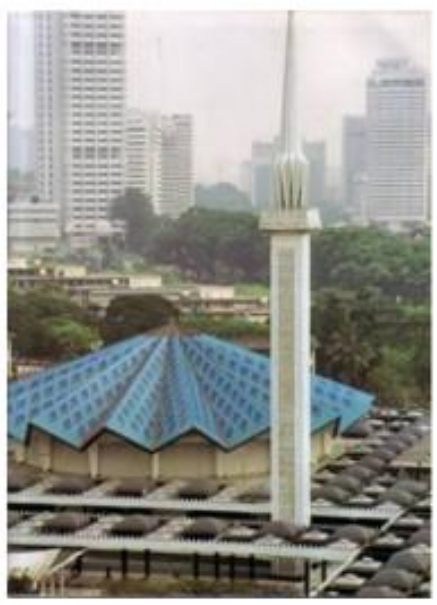

Gambar 23: Masjid Negara (Sumber:Utaberta \& Rasdi, 2010). 


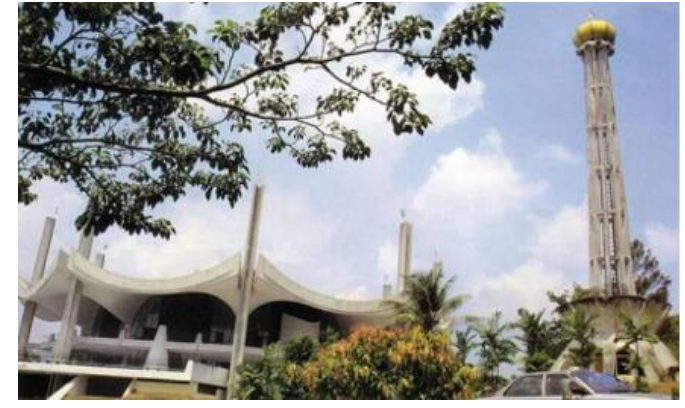

Gambar 24: Masjid Negeri Sembilan (Sumber:Utaberta \& Rasdi, 2010).
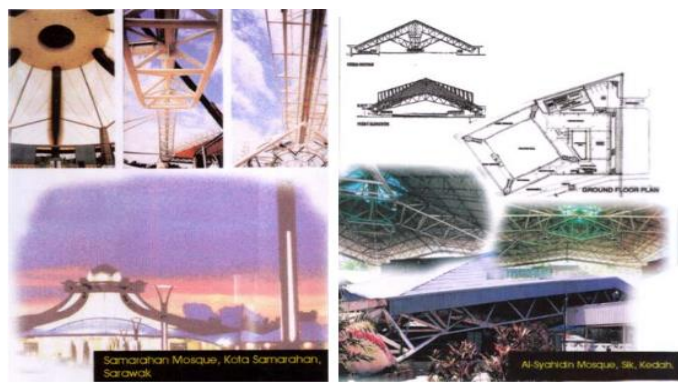

Gambar 25: Denah dan konstruksi masjid (Sumber: Collins, 1998)

Masjid Negara merupakan kombinasi hasil reinterpretasi modernistik dan arsitektur Melayu tradisional. Masjid Negara memiliki deretan serambi atau beranda ruang. Dan Masjid Negeri Sembilan menggunakan atap dari bentuk gabungan dari cangkang beton bertulang berbentuk kerucut (gambar 25). Bentuk ini merujuk pada atap pelana dari tanduk kerbau dari rumah Minangkabau. Sistem struktur utama menggunakan rangka beton bertulang. Atapnya terbentang secara bebas untuk mendapatkan ruang sholat tanpa kolom. Pelat atap dengan lipatan atau cangkang kerucut yang berpotongan terlihat progresif yang melekatkan dinamisme dalam Islam(Rasdi \& Tajuddin, 2007).

\section{Post Modern Revivalism}

Masjid dengan skala besar ini menjadi suatu pernyataan tentang kejayaan Islam setempat dan bahasa yang digunakan oleh kerajaan negeri dan kerajaan federal untuk mengekspresikan kepedulian ciri lokal atau vernakular yang dalam untuk kepentingan simbol-simbol keislaman.
Ciri yang muncul berupa kompleks yang memiliki pagar dan mewah. Fasilitas keindahan berupa air mancur, tanah beraspal, dan padang rumput dengan banyak ornamen pahatan di lansekap. Letak masjid ini berada di atas titik tertinggi, di tengah danau buatan atau terisolasi dari kain perkotaan. Jenis ini dapat dilihat pada Masjid Putra Jaya, Masjid Shah Alam, Masjid Wilayah Persekutuan dan Masjid Perta Jaya yang dapat dilihat pada gambar 26, 27, 28 dan 29.

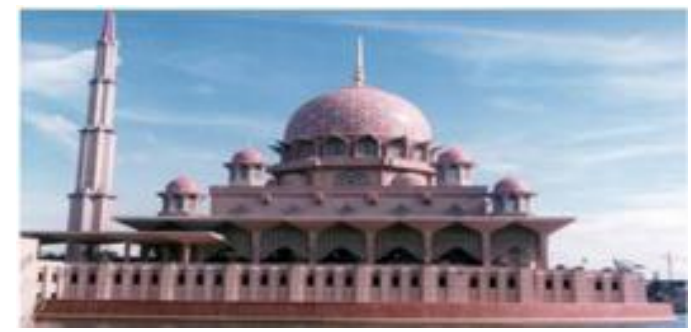

Gambar 26: Masjid Putra Jaya (Sumber:Utaberta \& Rasdi, 2010)..

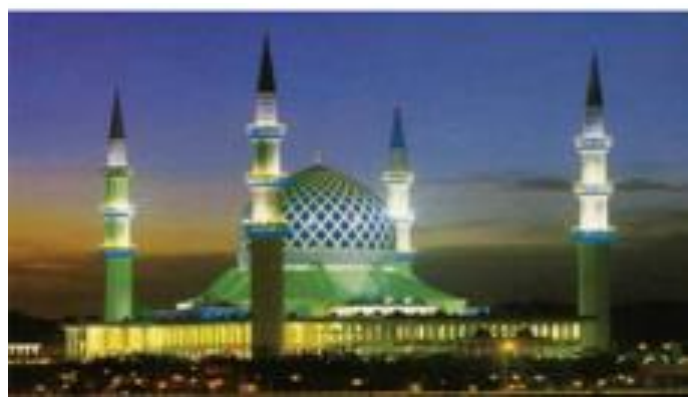

Gambar 27: Masjid Shah

(Sumber:Utaberta \& Rasdi, 2010).

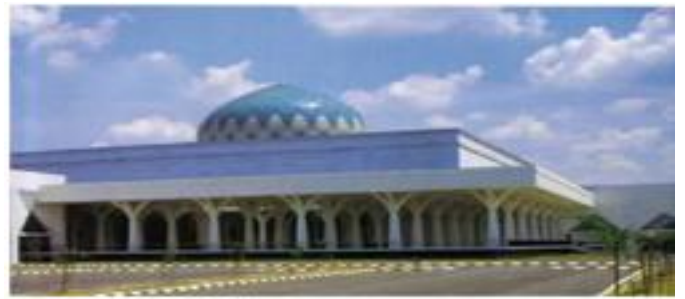

Gambar 28: Masjid Wilayah Persekutuan (Sumber: Utaberta \& Rasdi, 2010).

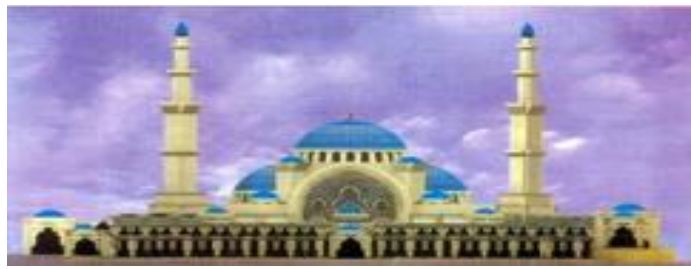

Gambar 29: Masjid Petra Jaya (Sumber: Utaberta \& Rasdi, 2010). 
Masjid jenis ini umumnya terbuat dari konstruksi beton bertulang dengan kubah berusuk baja. Marmer dan ubin impor yang menyelimuti seluruh masjid. Selain itu, elemen masjid juga yang memberikan suasana segar dalam penggunaan rangka kayu modern, dinding yang berlapis interior, dan railing bahan baja tempa

Tabel 4. Perbandingan Karakteristik Masjid Melayu Malaysia berdasarkan Gaya Arsitektural

\begin{tabular}{ll}
\hline \multicolumn{1}{c}{ Daerah } & $\begin{array}{c}\text { Karakteristik gaya masjid } \\
\text { Malaysia }\end{array}$ \\
\hline - Kampung Hulu, & Gaya Vernakular Tradisional \\
Melaka & \\
- Kampung & \\
Pangkalan & \\
Kakap, Kedah \\
- Kampung \\
Tengkera, \\
Melaka
\end{tabular}

yang mengelilingi ruang serambi dan sekitarnya (Rasdi \& Tajuddin, 2007)

\section{Perbandingan Arsitektur}

Adapun perbandingan Karakteristik Masjid Melayu Malaysia berdasarkan Gaya Arsitektural dapat dilhat pada tabel 4 berikut

\section{Daerah Karakteristik bentuk, ruang, dan susunan}

Masjid ini memiliki bentuk kubus dengan lima tiang utama tanpa ukiran. Struktur rangka dengan sistem tiang gantung menggunakan struktur atap berlapis tiga (Masjid Kampung Laut dan Masjid Kampung Tuan), atap berlapis dua (Masjid Papan dan Masjid Lenggeng) dan atap memanjang pada Masjid Langgar (Rasdi \& Tajuddin, 2007)

Johor Bahru, $\quad$ Gaya Klasik Eropa
Johor Malaysia
Johor Malaysia

Memiliki lengkungan setengah lingkaran diantara kolom dan kubah (dome) dan Lengkungan setengah lingkarannya pada jendela dan pintu masjid. dan dilengkapi dengan pilaster cornice (Rasdi \& Tajuddin, 2007)

Semenanjung, $\quad$ Gaya Sino-Elektrik
Malaysia

Memiliki bentuk lempengan yang ditinggikan sekitar setengah meter dengan tangga batu menuju lantai utama, memiliki ruang area sholat dan serambi yang tertutup mengelilingi lantai utama, struktur atap masjid bersusun ganda dengan bubungan dan papan fasia dengan hiasan motif tanaman. Puncak atap dihiasi mastaka berupa patung bulat meruncing serta memiliki perbedaan struktur pada bentukan atapnya berupa berlapis dua dan berlapis tiga(Ahmad, 2015)

\begin{tabular}{|c|c|c|}
\hline $\begin{array}{l}\text { Bukit Chan dan, } \\
\text { Kuala Kangsar, } \\
\text { Perak, Malaysia }\end{array}$ & Gaya India Utara & $\begin{array}{l}\text { Masjid ini memiliki banyak Menara dan kanopi kubah kecil, } \\
\text { gerbang berbentuk sarung kaki kuda dengan tiang yang } \\
\text { penuh dekorasi, struktur masjid memiliki lengkungan } \\
\text { multifoil diatas kolom yang dihias (Utaberta \& Rasdi, 2010) }\end{array}$ \\
\hline $\begin{array}{l}\text { Kuala Lumpur } \\
\text { Seremban }\end{array}$ & Gaya Modernistik & $\begin{array}{l}\text { Bentuk mengkombinasikan reinterpretasi modernistik } \\
\text { arsitektur Melayu tradisional dengan piring terlipat dengan } \\
\text { kubah memiliki metafora payung kerajaan, Struktur } \\
\text { menggunakan pilar empat rangkaian yang diperkuat beton } \\
\text { berbentuk kerucut untuk merujuk pada atap pelana, atap } \\
\text { terbentang secara total dan unik, dinding kiblat memakai } \\
\text { struktur berdiri bebas, seluruh lantai dilapisi dengan pagar } \\
\text { setinggi } 1 \mathrm{~m} \text { dan ornamen pelat yang terlipat dan cangkang } \\
\text { kerucut yang berpotongan memperlihatkan progresif } \\
\text { dinamisme Islam(Rasdi \& Tajuddin, 2007) }\end{array}$ \\
\hline $\begin{array}{l}\text { Bandar Jerteh, } \\
\text { Besut Terengganu } \\
\text { Darul Iman }\end{array}$ & Gaya Vernakular Modern & $\begin{array}{l}\text { Struktur utamanya menggunakan struktur beton bertulang } \\
\text { dan dinding bata yang diplester, struktur atap piramida } \\
\text { mengkombinasikan kubah kecil dan kubah tunggal, memiliki } \\
\text { satu atau dua Menara serta ruang area sholat pria dan wanita } \\
\text { berada dalam satu ruangan dengan partisi(Nasir, 1995) }\end{array}$ \\
\hline Bandar Kuantan & Post Modern Revivalism & $\begin{array}{l}\text { Tipologi masjid menggunakan teknologi modern dan } \\
\text { menggambarkan kemewahan, desain dipengaruhi oleh } \\
\text { bentuk budaya asing dan Bahasa daerah revivalism dan } \\
\text { struktur utama menggunakan beton bertulang dan } \\
\text { baja(Rasdi \& Tajuddin, 2007) }\end{array}$ \\
\hline
\end{tabular}

Sumber: hasil analisis, (2020) 
Studi perbandingan arsitektur pada tabel 1 memperlihatkan pengaruh adat istiadat dan budaya terhadap arsitektur Melayu. Rumah Tradisional Melayu di Malaysia memiliki tipologi rumah panggung dan memanjang. Bentuk arsitektur ini untuk memenuhi kebutuhan orang Melayu. Pengaruh budaya lokal dan budaya asing dapat terlihat dari perubahan arsitektur Rumah Tradisional. Tabel 1 memperlihatkan Bumbung Panjang merupakan bentuk dasar yang umum digunakan, bentuk Lima/Limas merupakan pengaruh budaya asing dan bentuk Bumbung Perak Limas merupakan alkulturasi budaya asing. Bentuk ini sebagai modifikasi bentuk Bumbung Lima menjadi arsitektur yang memiliki unsur Melayu. Perbedaan pada arsitektur Rumah Tradisional Melayu terdapat pada penamaan dan penempatan ruang, bentuk atap, ornamen ruang, dan struktur yang menggambarkan besarnya pengaruh budaya lokal dan asing.

Pada tabel 4 perbandingan arsitektur masjid Malaysia memiliki persamaan dan perbedaan terhadap elemen arsitektural. Perbedaan pada gaya karakteristik vernakular tradisional memiliki 3 jenis atap yakni masjid yang memiliki atap berlapis tiga (Masjid Kampung Laut dan Masjid Kampung Tuan), masjid yang memiliki atap berlapis dua (Masjid Papan dan Masjid Lenggeng). Kedua Jenis masjid ini memiliki atap berbentuk piramidal dua tingkat. Jenis terakhir, masjid memiliki atap memanjang berupa pelana dan mirip dengan bentuk atap rumah tinggal (Masjid Langgar). Persamaan vernakular tradisional yang ditemukan dari ketiga jenis masjid adalah tidak adanya Menara. Masjid Sino-Eklektik memiliki perbedaan struktur pada bentukan atap, yaitu masjid dengan atap berlapis dua dan masjid dengan atap berlapis tiga. Masjid SinoEklektik bertingkat tiga ditemukan pada
Masjid Kampung Hulu, Masjid Tengkera, dan Masjid Kampung Keling di Melaka atau Masjid Undang Kamat dan beberapa masjid lain di Negeri Sembilan. Masjid yang bertingkat dua dapat ditemukan pada Masjid Undang Serun di Negeri Sembilan. Berbeda dengan masjid tradisional yang terletak di daerah perkampungan, masjid jenis ini banyak terdapat di perkotaan seperti Melaka, Penang dan Negeri Sembilan.

Masjid Malaysia dapat dibedakan dalam dua jenis struktur modernistik di yaitu Ekspresionisme Modernistik dan Strukturalisme Modern. Modernistik ekspresionisme mengklasifikasikan bentuk metafora melalui bentuk ekspresi struktur. Modernistik strukturalisme mengklasifikasikan ekspresi struktur hanya dengan melihat saja. Ketiga gaya tersebut memiliki perbedaan jenis struktur pada lapisan atapnya, sedangkan fakta persamaannya terlihat pada gaya vernakular tradisional. Elemen gaya masjid sino elektrik dan modernistik memiliki perbedaan struktur, bentuk dan susunan yang berbeda. Ketujuh gaya arsitektur ini memiliki persamaan pada susunan pola ruangnya, penggunaan material dinding kiblat berupa struktur berdiri bebas dan kokoh, serta seluruh lantai dilapisi dengan pagar setinggi satu meter. Variasi gaya arsitektur ditemukan pada desain masjid di Malaysia ini yang mencolok sebagai gagasan tentang kosakata 'Arsitektur Islam' yang definitif dan meninggalkan keinginan banyak hal karena menunjukan tidak ada preferensi untuk gaya tertentu yang diulang (Yusoff \& Sulaiman, 2004).

\section{Kesimpulan}

Rumah Tradisional Melayu di Malaysia merupakan bangunan dengan arsitektur khas, berkarakter, dan layak untuk dilestarikan serta dijaga keberadaannya. Jika dilihat dari masa bangunan rumah Melayu Malaysia terdiri dari rumah induk 
atau rumah utama dan dapur, penghubung rumah induk dan dapur disebut Langkau Betang. Tipologi rumah tradisional Melayu di Malaysia dibedakan dari bentuk atapnya yaitu rumah dengan bentuk atap Bumbung Panjang, Bumbung Lima, dan Bumbung Perak. Bumbung Limas yang merupakan perubahan bentuk dari pengaruh luar seperti belanda maupun budaya setempat. Bumpung Panjang merupakan bentuk tipologi rumah yang paling banyak dan umum di Malaysia dengan ciri khas atap pelana panjang dan rumah panggung. Sudut rumah tinggal terdapat berbagai macam jenis ornamen, seperti ornamen Selembayung atau Tanduk Buang, motif tombak yang terhunus disebut tombak-tombak, atau motif sayap layang-layang di sudut cucuran atap.

Penggunaan bentuk atap piramidal ditafsirkan sebagai tiruan masjid di Jawa tempat Islam telah menjadi kekuatan politik yang kuat. Seluruh kesan masjid dapat digambarkan sebagai bangunan dengan atap datar. Pada penjelasan arsitektur Masjid Tradisional dan SinoEklektik kebanyakan hanya berdasarkan pada bentuk fisik seperti atap pada bangunan saja, sementara untuk jenis masjid yang lain sangat dipengaruhi oleh langgam gaya-rupa, pengaruh arsitektural dan teknologi yang digunakan di Malaysia. Tipologi masjid seperti ini ditaati secara religius oleh banyak orang sebagai bentuk masjid terkait kesucian bentuk. Ketujuh gaya bahasa arsitektur masjid yang disajikan dapat diklasifikasikan dengan menjelaskan berbagai karakteristik dari setiap gaya dan alasan pemilihan bentuk masjid tersebut.

\section{Pernyataan penulis}

Dengan ini penulis menyatakan bahwa penelitian ini terbebas dari konflik kepentingan dengan pihak manapun

\section{Ucapan Terimakasih}

Ucapan terima kasih disampaikan kepada semua pihak yang telah berperan dalam pembuatan artikel ilmiah, khususnya civitas akademik di Jurusan Arsitektur Universitas Tanjungpura.

\section{Referensi}

Afifi, H. M. (2017). Thermal Comfort in Rumah Kutai. Proceedings of International Conference on Architecture 2017 (ICRP-AVAN), 5.

Ahmad, A. A. (2015). Ruang dalaman Masjid Melayu tradisional Semenanjung Malaysia. Akademi Pengajian Islam, Universiti Malaya.

al-Āṭī, Ḥammūdah 'Abd. (1998). Islam in Focus. American Trust Publications.

Angkasa, Z. (2016). Arsitektur Melayu Berbasis Islam dan Relevansinya dalam Desain Gedung UIN Raden Fatah Palembang. 1-14.

Asif, N., Utaberta, N., \& Sarram, A. (2019). Architectural Styles of Malaysian Mosque: Suitability In Compact Urban Settings. MATEC Web of Conferences, 266, 06001.

https://doi.org/10.1051/mate cconf/201926606001

Azhari, N. F. N., \& Mohamed, E. (2012). Public Perception: Heritage Building Conservation in Kuala Lumpur. Procedia - Social and Behavioral Sciences, 50, 271279.

https://doi.org/10.1016/j.sbsp ro.2012.08.033

Aziz, S. M. (2013). The Construction of Malay Identity In The Media: A Literature Review. The 9th Regional Symposium of the Malay Archipelago 2012, 1-16. https://jadinti.uitm.edu.my/im ages/Volume22_Dec2018/INTI V22Dec2018_Complete_V1.pdf

Brace, C. L. (2003). The concept of race in physical anthropology. Research Frontier, 240-255. 
Choo, I. A. H., Rashid, M. S. A., \& Jamaluddin, N. H. (2020). The typology of rumah limas bumbung perak (RBLP). Planning Malaysia, 18(2). https://doi.org/10.21837/pm. v18i12.740

Collins, P. (1998). Changing Ideals in Modern Architecture, 1750-1950 (2nd edition). McGill-Queen's Press - MQUP.

Effendy, T. (2013). Lambang dan falsafah dalam seni bina Melayu. Yayasan Tenas Effendy bekerjasama dengan Dinas Kebudayaan dan Pariwisata, Provinsi Riau, Indonesia.

Embong, A. M., Jusoh, J. S., Hussein, J., \& Mohammad, R. (2016). Tracing the Malays in the Malay Land. Procedia - Social and Behavioral Sciences, 219, 235-240. https://doi.org/10.1016/j.sbsp ro.2016.05.011

Firzal, Y. (2011). Malay House, an Uniqueness of Architetural Design Form. Local Wisdom: Jurnal Ilmiah Kajian Kearifan Lokal, 3(1), 19-24. https://doi.org/10.26905/lw.v 3i1.1388

Gaspersz, S. G. (2017). Masuk Melayu: Menegosiasikan Islam dan Kemelayuan di Malaysia. CivicCulture: Jurnal Ilmu Pendidikan PKN dan Sosial Budaya, 1(1). https://doi.org/10.31219/osf.i $\mathrm{o} / \mathrm{wdm} 5 \mathrm{c}$

GhaffarianHoseini, A., \& Dahlan, N. D. (2012). The Essence of Malay Vernacular Houses: Towards Understanding the Sociocultural and Environmental Values. Journal of the International Society for the Study of Vernacular Settlements (ISVS e-Journal), 2(2), 53-73.
Harun,
$\mathrm{N}$.
(2005).

a-with-cover-page-v2.pdf.

Buletin Perancang, JPBD, UiTM Perak, 100.

Hassan, A. S., \& Nawawi, M. S. A. (2014). Malay Architectural Heritage on Timber Construction Technique of the Traditional Kampung Laut Old Mosque, Malaysia. Asian Social Science, 10(8), p230.

https://doi.org/10.5539/ass.v 10n8p230

Hassan, A. S., \& Ramli, M. (2010). Natural Ventilation of Indoor Air Temperature: A Case Study of the Traditional Malay House in Penang. American Journal of Engineering and Applied Sciences, 3(3), 521-528. https://doi.org/10.3844/ajeas sp.2010.521.528

Hosseini, E., Mursib, G., \& Shahminan, R. N. R. (2016). Implementation of Traditional Malay Design Values in Contemporary Malay Houses. International Journal of Built Environment and Sustainability, 3(2), Article 2. https://doi.org/10.11113/ijbes .v3.n2.125

Johar, S., Che-Ani, A. I., Tawil, N. M., Surat, M., \& Kamaruzzaman, S. N. (2013). Preliminary Survey and Defects Analysis of Traditional Timber Mosques in Malaysia. Wseas Transactions on Environment and Development, 9(1), 11.

Lim, J. Y. (1987). The Malay House: Rediscovering Malaysia's Indigenous Shelter System. Institut Masyarakat.

Nasir, A. H. (1985). Pengenalan Rumah Tradisional Melayu Semenanjung Malaysia. Darul Fikir.

Nasir, A. H. (1995). Seni bina masjid di dunia Melayu-Nusantara.

Sejarah_dan_Pengaruh_Senibin 
Penerbit Universiti Kebangsaan Malaysia.

Prayogi, A. (2016). Dinamika Identitas

Budaya Melayu Dalam Tinjauan

Arkeo-Antropologis.

Tamaddun: Jurnal Kebudayaan dan Sastra Islam, 16(1), 1-20.

Rasdi, M. T. M., \& Tajuddin, M. (2007). Mosque architecture in Malaysia: Classification of styles and possible influence. Journal Alam Bina, 9(3), 1-37.

Rumondor, P., \& Manese, R. M. (2020). Eksistensi Masjid Di Perkotaan dalam Pengembangan Pendidikan Agama Islam. In Proceding The First International Conference on Islamic Thought (ICIT) IAI Al Khairat. The First International Conference on Islamic Thought (ICIT) IAI Al Khairat, PAmekasan. IAI Al Khairat. https://doi.org/10.31219/osf.i o/s3cjh

Said, S., \& Embi, M. R. (2008). A Parametric Shape Grammar of the Traditional Malay LongRoof Type Houses. International Journal of Architectural Computing, 6(2), 121-144. https://doi.org/10.1260/1478 07708785850113

Sandelowski, M., Leeman, J., Knafl, K., \& Crandell, J. L. (2013). Text-incontext: A method for extracting findings in mixedmethods mixed research synthesis studies. Journal of Advanced Nursing, 69(6), 14281437.

https://doi.org/10.1111/jan.1 2000

Tamrin, H. (2017). Enkulturisasi dalam kebudayaan melayu. Al-Fikra: Jurnal Ilmiah Keislaman, 14(1), 98-148. https://doi.org/10.24014/af.v $14 \mathrm{i} 1.3903$
Utaberta, N., \& Rasdi, M. T. M. (2010). Deskripsi tipologi, klasifikasi dan analisis perancangan masjid di malaysia. El-Harakah, 12(3), 179-193. https://doi.org/10.18860/el.v $0 \mathrm{i} 0.451$

Wahab, M. H. A., \& Bahauddin, A. (2019). The spatial organization of the Negeri Sembilan traditional house, Malaysia. Journal of Comparative Cultural Studies in Architecture, 21-28.

Yusoff, Y. M., \& Sulaiman, M. A. (2004). Kajian Tentang Maklum Balas Masyarakat Terhadap Aktiviti Masjid-masjid Negeri di Semenanjung Malaysia. Jurnal Usuluddin, 20, 201-222.

Zain, Z. (2016). The Ecological Responsive Buildings: Traditional House in the Kapuas Riverside of West Kalimantan. Komunitas: International Journal of Indonesian Society and Culture, 8(2), 295-308. https://doi.org/10.15294/kom unitas.v8i2.5836

\section{Kontribusi Penulis}

Zairin Zain berkontribusi pada metodologi, supervisi penelitian, validasi dan melakukan penelaahan artikel

Uray Najwa Amalia berkontribusi pada konseptualisasi, pengumpulan data dan investigasi, menyusun draft artikel dan editing.

Silvia Christabella berkontribusi pada pengumpulan data, analisis data, dan penyusunan draft artikel serta visualisasi data 